\title{
Learning Experiences of Gifted Young String Players in the Taiwan Milieu
}

\author{
Chia-Hui Liu \\ Diwan College of Management, Taiwan
}

The purpose of this study was to investigate the development of the learning experiences of gifted young string players in Taiwan. Nine musicians under the age of 40, who had been accepted into music programs for the gifted, were invited to discuss their experiences and the development of their careers. Thorough interviews were conducted and then analyzed using a grounded theory approach. The findings of this study indicate that the training of the string players depended on 5 key elements: music abilities, music temperament, learning processes, features of their learning experiences, and the influence of the social context in Taiwan.

\section{Introduction}

\section{Background of the Study}

There is a 44-year history of special classes for musically talented students in Taiwan; however, in the early years, it was difficult for such students to obtain a high-quality music education. There were no professional musicians in Taiwan, so it was not a suitable environment for a talented student. Professors and lecturers suggested to their students that they go abroad to further develop their talents. At that time (1962), however, there was Martial Law in Taiwan and it was difficult to leave the country. Thus, the Ministry of Education (MOE) passed the Musically Talented Students' Study Abroad Law in 1962, which made it possible for talented students to leave the country and study in Europe or the United States. This law ceased in 1973. Although musically talented students could still study abroad,

Chia-Hui Liu is an Assistant Professor of Department of Early Childhood Education at Diwan College of Management in Taiwan.

Journal for the Education of the Gifted. Vol. 32, No. 2, 2008, pp. 245-274. Copyright (C2008 Prufrock Press Inc., http://www.prufrock.com 
their families had to pay very large sums of money to fund the opportunity. With opportunities abroad becoming less feasible, the first Musically Experimental Class was set up by the private Guangren (Catholic school) elementary school in 1963 and offered opportunities domestically for Taiwan's musically talented students.

Nearly 10 years later, the MOE created new regulations and established the first public classes (Musically Experimental Classes) for musically talented students in 1974. A primary reason for the public classes was that young students experienced difficulty adapting to life and study abroad. Furthermore, the tuition and living expenses were a significant financial burden for the parents, so relatively few young students could study abroad.

Meanwhile, domestically, music professor abilities and learning equipment had improved after 1970 . So, in order to let the most musically talented children have special training, the MOE opened classes for musically talented students all across Taiwan. Further, the MOE expanded the age range of the classes to include students from grade 3 to grade 12 . Most importantly, the musically talented education program incorporated the Special Education Law in 1984, allowing them to receive financial support from the government.

Almost a half century has passed since the first classes for musically talented students were held, and recent follow-up studies concerning musically talented students showed (a) in the musically talented classes, most students were female (86.9\%); (b) among the female musically talented students, the majority aspired to be music teachers in the musically talented classes, regular classes $(87 \%)$, or university departments of music (5\%), and some wished for a career as a symphony orchestra professional performer (3\%); (c) most of them continued to study at the musically talented classes (86\%); and (d) most of them were satisfied with their lifestyle or career development $(70 \%$; Kuo, 2003, 2004). The studies showed the positive results of this self-contained musically talented education system.

Unfortunately, the resultant careers of some graduates from the musically talented classes have been unsatisfactory for some of the domestic musicians. The government had invested a lot of money into these classes and expected Taiwanese music stars to appear on the world stage. The reality, however, is that most of the musically talented students became music teachers. A few of them became sym- 
phony orchestra performers. Rarely did they become professional performers. Some studies explain these resultant careers with the following rationales: (a) the curriculum was incoherent or repetitious; (b) the career development was too narrow, concentrating too much on musical expertise skills (68.6\%), and $48.6 \%$ of musically talented students could not pursue both music and academic studies because the entrance examinations demanded the most exceptional score $(\mathrm{Li}$, 2001, p. 81); (c) the government did not develop performance hardware, such as recital halls; and (d) the government did not offer scholarships for young musicians to study abroad (Kuo, 2003, 2004).

In the early 1990s, Taiwanese society became more interested in classical music because several famous musicians held concerts and recitals here. For example, the tenors Luciano Pavarotti, Placido Domingo, and José Carreras; violinist Anne-Sophie Mutter; and pianists such as Vladimir Ashkenazi and Martha Argerich all played in Taiwan. Although attention generated from such high-profile musical performances increased sales in these genres, most people preferred to enjoy the music at home on DVDs or CDs and did not attend the concerts. Thus, the classical music genre still had some difficulty attracting crowds to live performances. The public preferred to spend its money on pop music concerts, rather than on seeing young Taiwanese classical musicians perform onstage.

Many educators are now wondering how many of these musically talented students in Taiwan will become great classical musicians. They also want to know why is it so difficult to develop these musically talented students into great classical musicians in the local education system. The purpose of this study was to investigate the learning experiences of gifted young string players and how they dealt with obstacles during the course of their study.

\section{Research Questions}

Based on the motivation for the study, the research questions are as follows:

1. What are the music abilities and temperament of the gifted string players in Taiwan? 
2. What are the career development characteristics for the gifted string players who were accepted into a musically talented program in Taiwan?

3. What special social context affects the gifted string players' development as great performers in Taiwan?

\section{Review of the Literature}

\section{Studies of Music Ability and Temperament}

Music abilities are natural in humans, but not all can be great musicians, especially in the classical music field. Normally, musical abilities include pitch, rhythm, melody, and harmony. However, musically talented students have always had the ability of absolute musical memory, such that they could sing any song after hearing it; they used this memory to develop vocal performances, play instruments, or compose (Carroll, 1993; Gordon, 1989; Winner \& Martino, 2000).

Interest in music is one notable characteristic among musically talented students. Some felt that they could not live if they did not have music in their lives. For example, anecdotes about Mozart, Rubinstein, and Stravinsky indicated they were passionate about music from a very young age (Gardner, 1983; Winner \& Martino, 2000). Musically talented students also exhibit advanced music interpretation and expression. In addition, musically talented students possess high levels of creativity, which manifest in stage performances, improvisation, and composition. For example, cellist Yo-Yo Ma used Chinese traditional music instruments, Chinese songs, and the cello together in his work Silk Road; the album is so beautiful, sentimental, and exotic. Mozart, Frederic Chopin, Franz Liszt, and Sergey Rachmaninov were not only performers but also composers. Creativity helped them add new ideas into music (Gordon, 1989).

Davidson and Scripp (1994/1995) proposed the metaphor of concentricity of conditions of giftedness; a gifted individual who has musical talent needs family conditions to support the surrounding culture context for audiences to accept him or her. Accordingly, interactions with society were more important than an individual's 
talent. Regarding musical temperament studies, $\operatorname{Kemp}(1996,1997)$ found that string players' personalities have salient features, including aloofness, introversion, deliberation, and self-sufficiency. They tend to work with small groups, practice hard, and detach themselves from others.

\section{The Learning Career Development of Musically Talented Students}

During the Middle Ages, musicians worked for churches, courts, and noble families. Concerts became entertainment during the 18th century. Music was no longer just religious; people sang and played for enjoyment. Four transformations of musicians in Western history began in the 19th century. First, the composer was no longer the performer. The performer concentrated on how to interpret the music of a composer. Second, musically talented children mastered music earlier. Previously, musicians learned music after they were 10 years old, and they could play several instruments. Contemporary musicians mastered one instrument at a very young age, usually 4 or 5 years old. Third, performing skills demanded perfection. Young learners spent a lot of time practicing. Last, performance changed so that stars were created for the stage, especially soloists. Electronic media was spreading in the music field, providing new challenges to young musicians (Lebrecht, 2001; Lehmann \& Ericsson, 1998).

Bloom (1985) and Sosniak (1985a, 1985b, 1997) claim that concert pianists' learning could be divided into three stages. The early years are characterized by plentiful practice and positive learning experiences. Music is a part of family culture. The middle years are characterized by disciplined piano practice, dedicated teachers who facilitate their learning, and families sacrificing them to help them. The later years are characterized by learning from great musicians, meeting other young musicians, and living among musicians. These studies are similar to Liu's (2001) work. She studied three musicians in Taiwan, and she divided the learning career development into four stages: (1) interest stage, (2) learning exploration stage, (3) profession training stage, and (4) transforming stage. Based on the studies of Bloom, Sosniak, and Liu, the learning career development for talented young musicians, which includes individual characteristics, 
family involvement, schooling experiences, and the community context, are similar in the United States of America and Taiwan.

Subotnik and Jarvin (2004) developed a model for the development of abilities into competencies, expertise, and scholarly productivity or artistry for musically talented students at three elite American conservatories. They claimed the model could be divided into three stages. In the early stages, the initial attributes of musically talented students included intrinsic motivation, charisma, and musicality. Moreover, these attributes are not teachable. These attributes contribute to the development of competencies, mediated by variables such as learning characteristics (i.e., how many repertoires can be learned, their "teachabilities"), parental support or pressure, the quality of the student-teacher experience, and persistence through good and bad times. In the middle stage, competencies transition into expertise. The new mediating variables include understanding personal strengths and weaknesses, self-promotion and restoration of self-confidence, and adapting to and acquiring social skills. In the final stage, the transition is from expertise to scholarly productivity or artistry. The mediating variables are the variables from the middle stage and risk taking and charisma. Subotnik and Jarvin's study investigated more detailed and complicated factors than the studies of Bloom (1985), Sosniak (1985a, 1985b, 1997), and Liu (2001).

Feldman's (1991) conception "co-incidence" explains how child prodigies developed their potential. He used four time frames: (1) the individual's life, (2) the developmental history of the field or domain, (3) culture and historical trends that bear on both individuals and fields, and (4) the evolutionary time. It makes sense that the classical music development milieu in Taiwan would influence the career of young musicians. An old Chinese proverb states: "They have to be born at an opportune time, in a favorable geographical position, and with the support of the people. Then a great musician will come to the stage."

\section{Method}

This study was mainly based on qualitative methods in order to understand the special characteristics of the learning experiences and 
development of the young gifted string players. In-depth interviews were conducted to determine music ability, personality, and musical learning experience of the participants. To analyze the data, the researcher used a grounded theory approach.

\section{Participants}

Purposive sampling was used to identify the participants until theoretical saturation was reached. The background criteria for each participant were as follows: First, they must have worked in a musical field (e.g., in music instruction, as a member of a symphony orchestra, or as a private studio instructor, or they must have studied in a musical graduate school program). Second, they must have majored in string instruments, as it is difficult to master the associated playing skills. Third, they must have studied the string instruments from a very early age. According to the purposes of this study, participants were selected based on the following conditions:

1.They passed the formal identification procedure and entered the musically talented classes to study.

2. They had graduated from junior musical colleges or musical departments of universities or graduate schools.

3. They were under 40 .

4. They volunteered to share their experiences without receiving compensation.

Table 1 lists the background information of the participants.

\section{Guiding Questions}

The researcher elicited responses and guided conversation through a series of preselected questions and prompts. The questions and prompts were as follows:

1. Please introduce your present occupation.

2. Why did you want to study music? Why did you enter the musically talented class?

3. How did the system and curriculum help you to study music? Did it limit your study? Did the assessment and identification to be a musically talented student limit your study? 


\section{Table 1}

\section{Brief Information of Participants}

\begin{tabular}{|c|c|c|c|c|c|c|c|}
\hline No. & Education & Major & Sex & Age & $\begin{array}{l}\text { Grades studied } \\
\text { in musically } \\
\text { talented classes }\end{array}$ & $\begin{array}{l}\text { Total time } \\
\text { in musically } \\
\text { talented } \\
\text { classes }\end{array}$ & Occupation \\
\hline 001 & $\begin{array}{l}\text { Junior musical } \\
\text { college }\end{array}$ & Violin & M & 27 & $3-9$ & 7 years & $\begin{array}{l}\text { Symphony } \\
\text { orchestra }\end{array}$ \\
\hline 002 & $\begin{array}{r}\text { Master of music } \\
\text { art (overseas) }\end{array}$ & Cello & $\mathrm{F}$ & 27 & $3-12$ & 10 years & $\begin{array}{l}\text { Music teacher of } \\
\text { a junior high } \\
\text { school }\end{array}$ \\
\hline 003 & $\begin{array}{l}\text { Studying for } \\
\text { master's } \\
\text { degree }\end{array}$ & Violin & $\mathrm{F}$ & 24 & $1-12$ & 12 years & $\begin{array}{l}\text { Symphony } \\
\text { orchestra }\end{array}$ \\
\hline 004 & $\begin{array}{l}\text { Studying for } \\
\text { master's } \\
\text { degree } \\
\text { (overseas) }\end{array}$ & Violin & $\mathrm{F}$ & 23 & $1-12$ & 12 years & Graduate student \\
\hline 005 & $\begin{array}{l}\text { Studying for } \\
\text { master's } \\
\text { degree } \\
\text { (overseas) }\end{array}$ & Violin & $\mathrm{F}$ & 23 & $3-12$ & 10 years & Graduate student \\
\hline 006 & $\begin{array}{l}\text { Studying for } \\
\text { master's } \\
\text { degree }\end{array}$ & Violin & M & 25 & $1-12$ & 12 years & $\begin{array}{l}\text { Graduate student } \\
\text { and private } \\
\text { music teacher }\end{array}$ \\
\hline 007 & $\begin{array}{r}\text { Master of music } \\
\operatorname{art} \text { (overseas) }\end{array}$ & Cello & $\mathrm{F}$ & 37 & $5-12$ & 8 years & $\begin{array}{l}\text { Symphony } \\
\text { orchestra }\end{array}$ \\
\hline 008 & $\begin{array}{r}\text { Master of music } \\
\text { art (overseas) }\end{array}$ & Viola & M & 36 & $3-12$ & 6 years & $\begin{array}{l}\text { Symphony } \\
\text { orchestra }\end{array}$ \\
\hline 009 & $\begin{array}{l}\text { Doctor of } \\
\text { music art }\end{array}$ & Violin & M & 34 & $7-12$ & 6 years & $\begin{array}{l}\text { Professor of music } \\
\text { in department } \\
\text { of university }\end{array}$ \\
\hline
\end{tabular}

4. What were your parents' attitudes toward your study in the musically talented class?

5. What are your opinions regarding the environment of classical music in Taiwan?

6. Do you believe that modern popular music is currently hindering the development of contemporary classical music? Explain. 


\section{Analysis}

The researcher's approach to theory development was based on Glaser and Strauss' (1967) and Strauss and Corbin's (1998) grounded theory. Grounded theory is derived from data that the researcher systematically collected and then coded and analyzed throughout the research process (Strauss \& Corbin, 1998, p. 12). In other words, the researcher had to analyze the data, simultaneously apply techniques of induction and deduction, and verify theory development. The entirety of the process included open coding, axial coding, selective coding, and process coding.

Open coding. The analytic process included mapping the concepts over the data and classifying these concepts into several categories that represented their properties and dimensions. Examples are listed below:

Interviewer: Why did you want to learn music when you were a child?

Respondent: It was the environment [I grew up in] (musical environment) ... My home had a piano and my parents were interested in music (musical interest). My mother learned the piano before, so she bought the piano and my home has it (family had a musical instrument). My mother taught me how to play the piano. It just was fun and exciting to me. When I was 5 years old, my parents sent me to study music at the Yamaha Music School (musical school initiates the musical interest). I always felt music was such fun; it started as a kind of play. My parents guided me slowly to learn music (guidance) ... and lead to an artistic world (artistic world). (001, p. 2)

Interviewer: Did she [mother] sit behind you and watch you play the violin?

Respondent: Right. I played 2 hours every weekday, 4 hours during the weekend. If I missed one day, then I needed to make up 2 hours during the holiday. I stayed at home, practiced and practiced. I didn't like to play the violin for a while. (Practice character) 
Table 2

An Example of Open Coding of the Interview Data

\begin{tabular}{|c|c|c|}
\hline \multirow[b]{2}{*}{ The name of category } & \multicolumn{2}{|c|}{ Open coding } \\
\hline & Properties & Dimensions \\
\hline \multirow[t]{3}{*}{$\begin{array}{l}\text { The motivations for } \\
\text { learning music }\end{array}$} & $\begin{array}{l}\text { Musical environment of } \\
\text { family. } \\
\text { Parents' musical interest } \\
\text { and family had a musical } \\
\text { instrument. }\end{array}$ & $\begin{array}{l}\text { Maintain musical interest: } \\
\text { Mother pushed him to } \\
\text { practice and he didn't play } \\
\text { after school. }\end{array}$ \\
\hline & $\begin{array}{l}\text { Initiation: studies at Yamaha } \\
\text { music school or mother } \\
\text { taught their children. }\end{array}$ & \\
\hline & $\begin{array}{l}\text { Parents lead him to learn the } \\
\text { music. }\end{array}$ & \\
\hline
\end{tabular}

Interviewer: Did all the participants have the same experiences? It seems that I lost the right to play. Now, I recall that if I didn't practice violin during elementary school, it would be impossible for me to master the skills. (001, p. 5)

After identifying the appropriate concepts, the researcher clustered the same conceptions into one category and then wrote down the name of the category. Finally, the researcher developed the properties and dimensions of the category and used a tabulate to finish the open coding (see Table 2 for an example of open coding).

Axial coding. The process of axial coding involves relating the categories (as seen in Figure 1) via a combination of inductive and deductive reasoning, linking relating categories at the level of properties and dimensions afterwards. The axial coding emphasized causal relationships and tried to fit the codes into a basic frame of relationships. The relationships, including phenomena, causal conditions, context, intervening conditions, and action and interaction strategy consequences, integrated to create a structure and process.

The researcher found that all of the participants were raised in music-loving families. Six of the participants had some kind of musical instrument in their home before the age of 5 . There were four participants whose parents (mother, father, or both) were teachers. Out of these four, two of the parent combinations included music teach- 


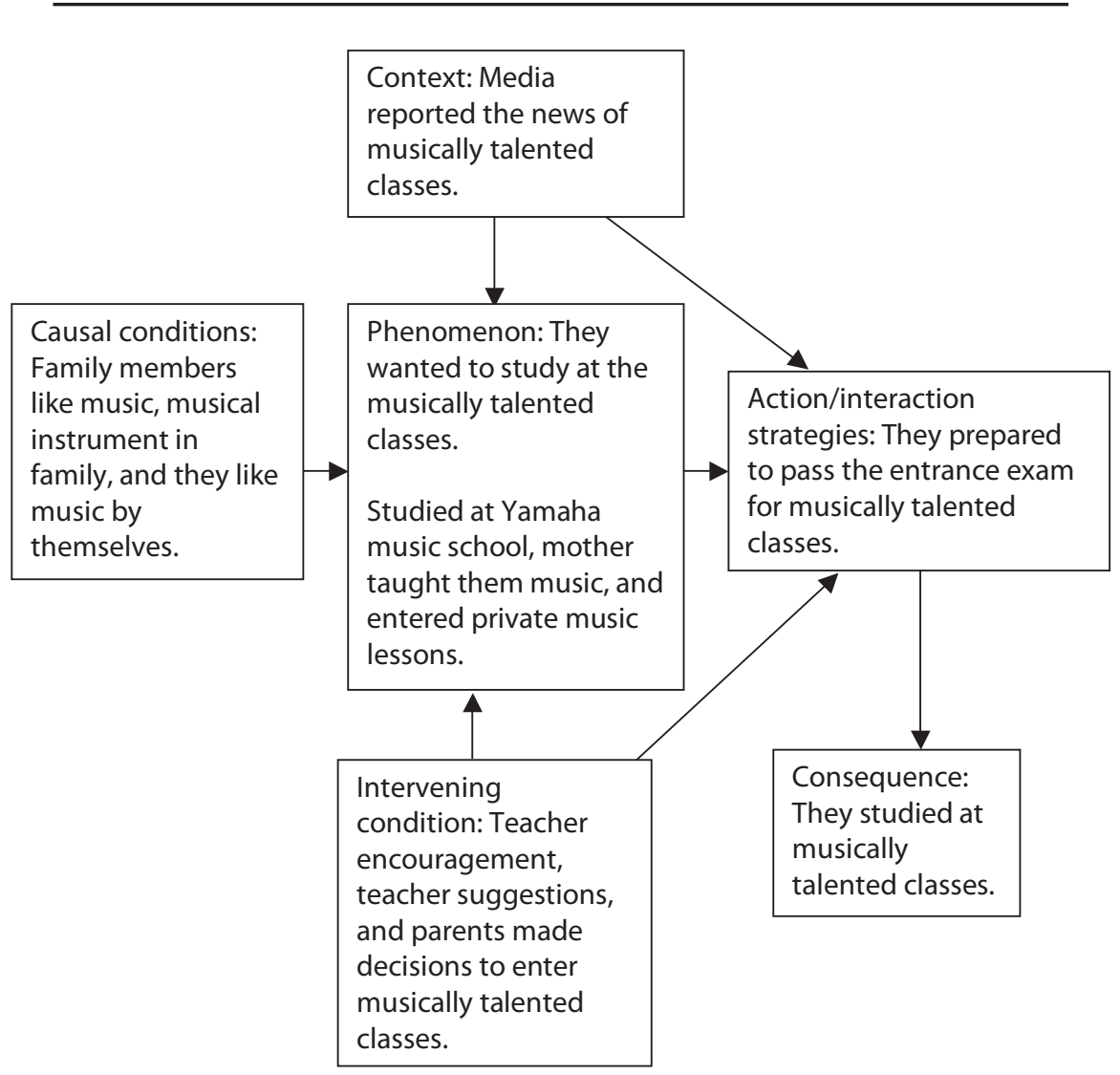

Figure 1. Axial coding relating structure and process.

ers whose other children (thus siblings of the participants) studied in musically talented classes. Among the other five participants, four of them entered the Yamaha Music School and studied with private teachers. The single remaining participant neither grew up in a musically talented family nor studied at the Yamaha Music School; he displayed his music talent while in kindergarten, and, at that time, his parents accepted the teacher's suggestion that he enter the premusically talented class at the elementary school.

Selective coding. The process of selective coding required that the researcher first identify the central category, then integrate all other categories into a single storyline and sort the memos that were 


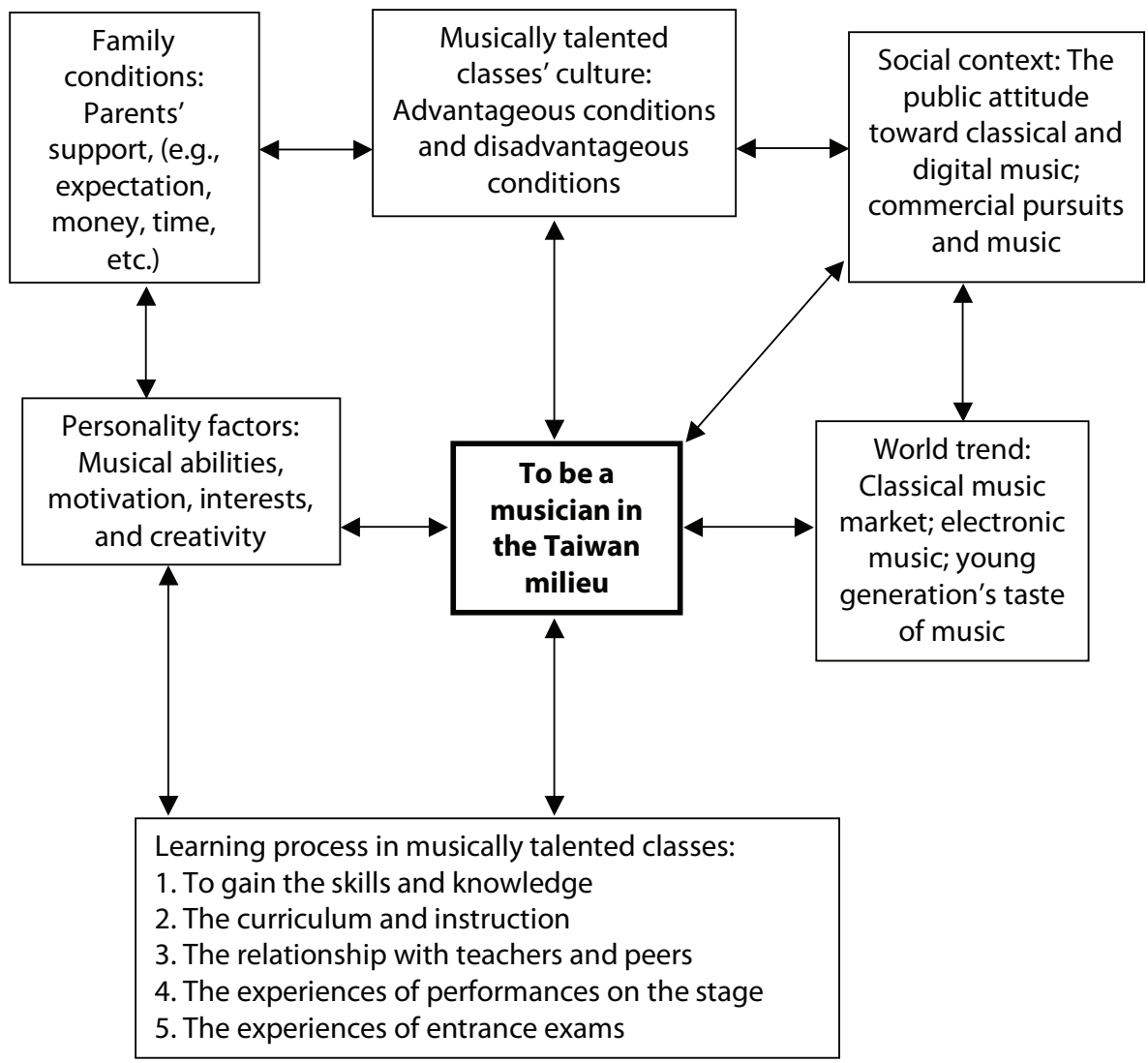

Figure 2. Example of selective coding: The factors that influence one to be a musician.

collected during the study. After completing the above task, the researcher had to test and verify the theory until it reached theoretical saturation. See Figure 2 for an example of selective coding of the interview data.

The researcher applied the Conditions and Consequences Matrix (see Figure 3) in order to consider the relationship between the social and personal conditions and consequences of the studies. The researcher took an explanatory account of the phenomenon under the participants' narration afterwards. 


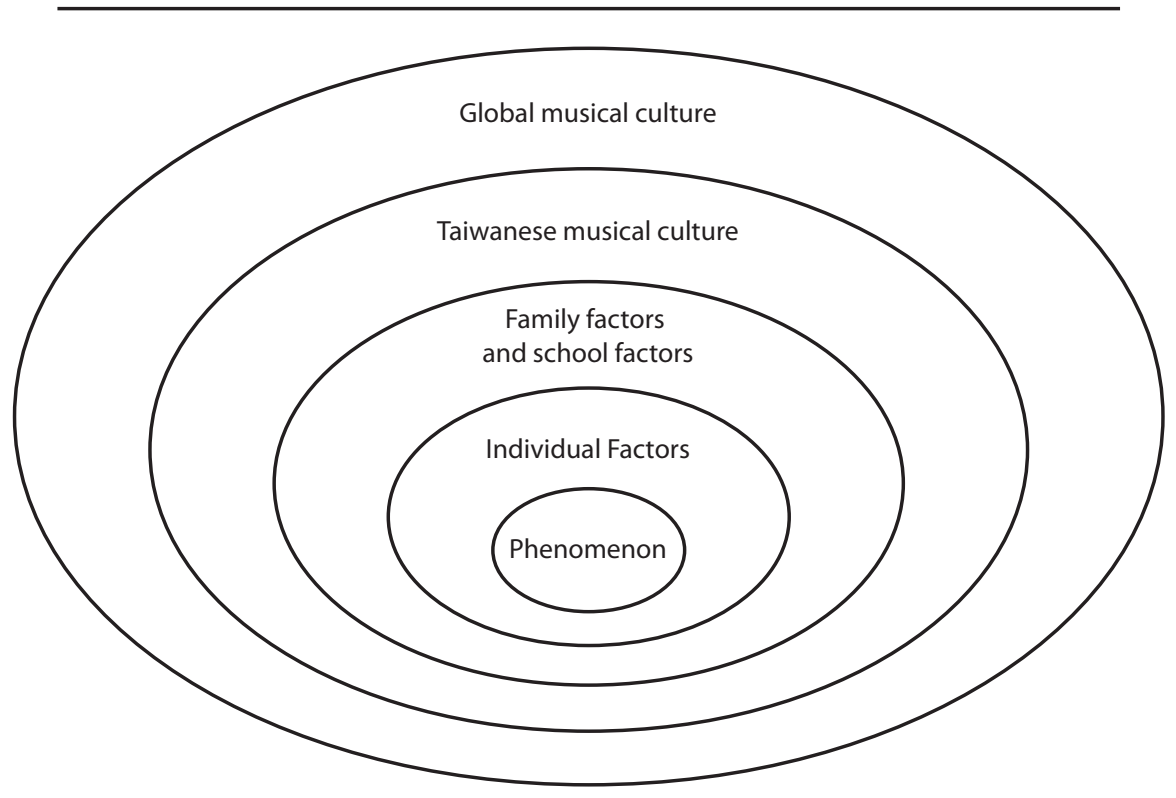

Figure 3. The conditions and consequences matrix.

Process coding. Process coding seeks to explicate phenomena in the context and time period in which it occurred and developed. When the temporary theory is formed, it needs to be tested to determine if any changes occurred. The process of learning development for the young musicians can be organized into stages or phases; moreover, process coding can verify the sequences of actions and interactions or property transformations (see Figure 4; Ho, 2004).

\section{Reliability and Validity}

First, the interview transcriptions were sent to the participants, and they rated the quality of exactness with an average score of $97 \%$ (100\% being perfectly accurate). Then, the researcher and coscorer, through discussing the interview questions, began to do the open coding separately. The researcher and coscorer discussed differences and revised the open coding until they reached consensus. Coding of the concepts between the researcher and coscorer were, on average, $84.97 \%$ similar, suggesting very reliable conclusions. 


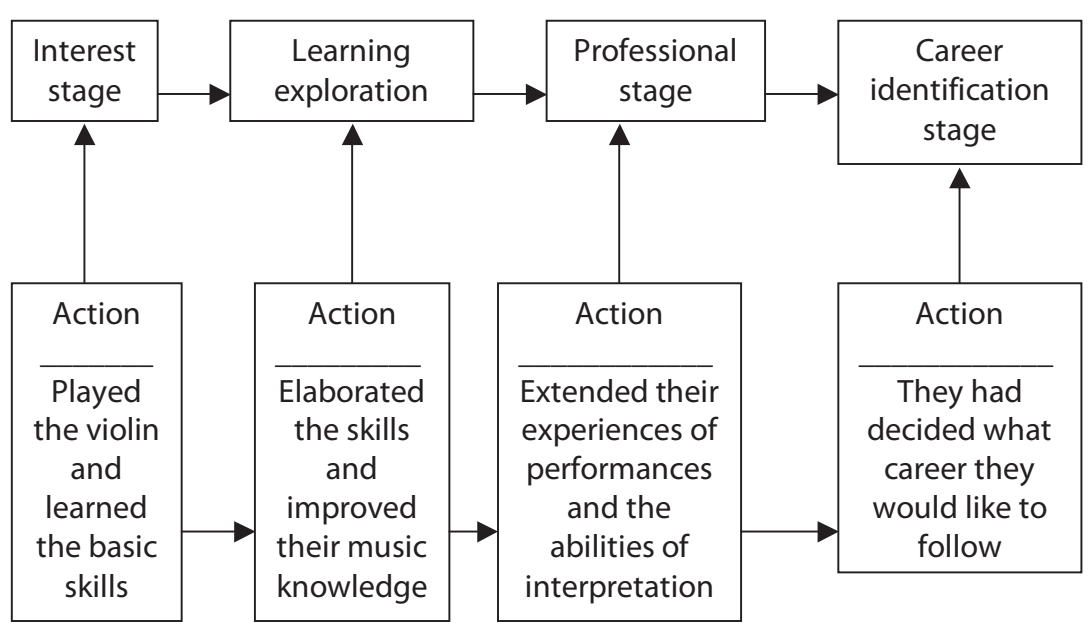

Figure 4. The stages of learning development for the young musicians.

Validity was addressed through triangulation. The researcher collected supplementary data, including interviews with two of the participants' mothers, students in the same musical talent classes, and the researcher's observation notes. The researcher invited a participant, a music department graduate student who was not musically talented, and a nonmajored music master to perform the support of cross-checking the information collected. The refutability principle, the constant comparative method, comprehensive data treatment, deviant-case analysis, and applied appropriate tabulations were used to ensure the validity of this study (Silverman, 2000).

\section{Findings and Discussion}

\section{Participants' Musical Abilities}

String players were raised in music-loving families. Usually both parents had a passion for music. The participants had access to musical instruments in their homes when they were young. They studied at the private musical cram schools (e.g., Yamaha Music School) when 
they were very young, where they were able to master their musical skills easily. Their musical abilities were stronger than that of their peers in sight-reading, and they appealed to audiences with their advanced music interpretation and solid performing style. These statements from the participants reflect their elevated musical ability even at an early age:

I remember when I was young, I went to the music class and it was easy for me to recognize the pitch. Then the teacher suggested to my mother, "She can try to learn to play the piano." (003, p. 3)

My music abilities were better than the others in performance. My musical interpretation was quite good and I did it by intuition. $(007$, p. 7$)$

\section{Participants' Music Temperament}

The string players all demonstrated strong motivation and were determined to be musicians. While they were studying in musically talented classes, most of their leisure time outside of class was spent playing string instruments as well. Music became the central part of their way of life; they even found that it was difficult for them to take time away from music. Thus, their interest in music developed into a passion. This is exhibited by the following set of statements by the participants:

When I heard the sound of music ... it made me feel so warm, it touched my heart ... In my job, my interests were all about the music ... It was incorporated as a part of my life. (001, pp. 6-7)

Music, it became more important for me. At first, I was interested in playing violin. Now, my everyday life is the music, I like it very much. (005, p. 7)

Two of them felt that their devotion was a terrible experience as they rarely socialized with other children. Conversely, five of them felt that playing their instruments became routine and second nature to them. They practiced daily, so they could bear being lonely and not 
part of a social peer group. Just as music is subjective, they became more individualistic. Moreover, they lived a hyper-competitive lifestyle, and they recounted that it was difficult for them to get along with others:

I had several classmates who were taught by the same teacher. They said that I was the teacher's pet. I thought that was unfair. My performance was better than theirs, and the teacher believed that I could play more skillfully and beautifully. (004, p. 15)

In their musically talented classes, they had a few selected friends in their field. The friendships improved their skills through discussions with one another:

She [the participant's wife] helped me when we were rehearsing; we gave some feedback to each other. I was so lucky, as my wife was like a confidante. I didn't know that I could find someone who, as an intimate friend, could help me like that. We grew up in this situation [in which] we practiced violin all day at home, and we didn't have a lot of social activities. Friendships were very limited, very limited. (001, p. 25)

\section{Participants'Learning Processes}

The learning process can be divided into four stages: (1) interest developing, (2) learning exploration, (3) professional training and (4) the career identification stage.

Interest stage ( 4 to 12 years old). The string players entered the musically talented classes. The basic programs included sight singing, dictation, music theory, and major and minor instruments. Five of the nine participants studied at private music cram schools as 4or 5-year-olds; the other four participants studied music with their parents' friends, school music teachers, or their own parents. These primary learning experiences were important for them to pass the entrance examination into the musically talented classes. During elementary school, they learned the basic skills of violin and had some recital experiences (see Appendixes A and B for charts describing the school system in Taiwan). 
Learning exploration (13 to 18 years old). In middle school, however, musically talented classes are limited. The main reason for this shortage was that the musically talented classes needed a lot of financial support from the local education bureau. This policy resulted in the entrance examination becoming very competitive. Furthermore, the curriculum of musical professional training took the place of traditional academic subjects, such as mathematics, science, art, and physical education, from elementary school through high school. The result was that it was difficult for musically talented students to return to the traditional academic curriculum in high school. Most of them decided to continue studying music. Some participants decided to enter senior high school to earn a graduation certificate, thus satisfying the prerequisite to sit for university entrance exams; other participants entered the junior music college after junior high school in order to concentrate on their music performance. Because junior music colleges do not award bachelor's degrees, participants who chose this option would not qualify as graduates from a university (see Appendix A and B for charts describing the school system in Taiwan). The following statements of the participants all demonstrate the rigors of their unique schedules and their learning and testtaking experiences:

During that time, academic subjects were more important than performance because everyone in our class would play very well. The scores became a dominant factor in that it determined who could enter senior high school's musically talented classes. I didn't like to spend too much time on academic subjects, so I decided to enter a junior music college. (0081, p. 2)

I liked to study all the time when I studied in senior high school, so I didn't spend much time to play violin ... In the university entrance exam I failed on the performance, not in the academic subjects. (005, p. 16)

Professional stage (19 to 22 years old). As they entered universities, the string players matured in their skills and in their music interpretation abilities. Moreover, they began to play many famous pieces from great composers with their classmates. Their experiences of playing 
with symphony orchestras were especially formative because it made them recognize the quality of their performances.

Two participants recalled that they had studied in the musical education departments of colleges that seek to train future music teachers. This was a trying time, as they really wanted to be professional performers instead of music teachers. The reasons for entering the teacher training colleges were as follows: (a) they were given the wrong career advice, (b) they could become a public school music teacher because this profession makes a steady income, and (c) the financial support was not enough for them to study music further (the teacher college's tuition was cheaper).

Teacher's colleges were the second target for most students...

Someone said it was difficult to find a job for those who were

learning music. My high school teacher encouraged me to study, and then my mother said that I had the right personality to be a teacher, it was the best choice. $(005$, p. 8$)$

Career identification stage (22 years old and beyond). All participants, except for the individual that worked in a symphony orchestra, continued studying music in graduate school. Their major musical instrument professors were famous musicians (professors from Western universities or conservatories). They began to accumulate experiences of performing on stage. They dreamed of becoming world-class musicians, but often the reality was that they would have to become a professor at a university or a member of a musical performing group:

Everyone was concerned with my learning process, my progress, when I studied abroad. I understood how to be a musician ... I gradually came to understand music and life. What music was and what life was. (009, p. 4).

\section{Features of the Participants' Learning Experiences}

In order to pass the competitive entrance examination so as to be admitted into the limited number of middle schools and music departments of universities, the string players had to adopt some special strategies in Taiwan. These strategies included the following: 
1. Participants took intensive music courses after school because their parents worried about their performances. During intensive music courses, they not only played violin or piano but also studied music theory and harmony, among other areas.

2. Participants learned a musical instrument from two teachers at the same time; one teacher was assigned by the school, and another teacher was from outside the school. The reason for the two-pronged approach was that the parents hoped their children could progress in their music skills more quickly. Furthermore, some participants explained that there were seldom "master classes" in Taiwan that provided a fitting study environment for musically talented students of their caliber. Consequently, the parents chose to pay the tuition to outside-school teachers. As one participant explained, "the parents thought that the teacher method outside the school was better" (006, p. 5).

3. Participants practiced an important piece for one year in order to master it. The musically talented students had to have perfect skills in order to gain the high scores or win the competitions necessary to enter the next stage of schooling. Although practicing only one piece for an entire year comes at the expense of practicing fundamental and varied skills, the music teachers, parents, and students had to compromise; forfeiting practicing the basic skills of playing in order to master one advanced piece helped the students in the short run. The following quotation describes the emphasis the students would place on perfecting one or a small number of selected pieces:

Sometimes, I practiced some basic skills. I only played one masterpiece in one semester when I was an elementary student. Then I played two or three masterpieces per semester when I studied in the middle school. Of course, the piece that I perfected was the exam piece. (003, p. 19)

4. After entering university, music majors commonly accepted outside work to accumulate performing experiences and to make money. All of the participants had the experiences of gigs, or performing music as a temporary job. There were three kinds of gigs: (a) playing string instruments in public symphony orchestras, (b) playing in private symphony orchestras, and (c) playing for some specific occasions. When they performed at symphony orchestras, it 
was difficult for them to make much money, but they did receive the additional benefit of extending their repertoires. Some participants preferred playing at private occasions (i.e., weddings, commercial promotions, clubs, etc.), as those jobs were easy to prepare for and often paid well.

5. Parents tended to invest a great deal of their time and money into their child's music education. One of the participants interviewed, a violinist, recalled the extra effort on the part of the mother in facilitating music study:

When I studied music, I had extra lessons of violin, piano, and music theory. We used to take a taxi. Finally, my mother learned to drive the car and picked me up, as it could save a lot of time. (005, interview's memo)

Parents also apparently offered their time and financial resources willingly, as they saw their child's music success as a future source of income and prestige. On the other hand, parents sometimes interfered with school administration by seeking well-known instructors and overemphasizing contest results. Behavior of this kind resulted in tension between the music classes and the families of the students. The culture and ecology of the musically talented classes were puzzling to these parents. Some participants recalled the uncomfortable feelings aroused when the parents would meet together to gossip about their children's achievements:

The phenomenon is quite serious, that parents compare the achievements of children. Some mothers of students took care with all their hearts of their children and paid attention to the children's progress. (the mother of 004, p. 4)

Consequently, all of the string players accumulated both happy and unhappy experiences throughout their studies. However, the impact of these experiences depended on how much effort they put in.

\section{The Influence of the Social Context}

The string players' dreams of becoming great musicians were not realistic, so they tried to get a job at a public school or (preferably) tried for a professor position at a university. It was difficult to make 
money from their performance because general music education in primary and secondary schools taught very little about classical music. Taiwanese society fails to provide sufficient support for classical music. As a result, there are few classical music aficionados in Taiwan, which in turn forces performers to reconsider the popularity of their repertoire as well as the impact of their performance on the audience. The participants recounted how they handled facing such lackluster reception of their musical abilities from the public:

Every child had listened to classical music from very young and appreciated it. A child then can listen to both the popular music and classic music when the child grows up. My brother played the trumpet in the musically talented classes but he liked jazz; I played a viola, and I listened to the popular music. Classical music was a part of life in the West. No wonder Westerners can listen to different kinds of music. (008, p. 7)

Generally speaking, the string players needed external environmental and individual conditions to become popular musicians in Taiwan.

\section{External Environmental Conditions}

When the musically talented students graduated from university, their next challenge was to establish their career as a music performer on stage. The researcher found that there are two sets of conditionsexternal environmental and individual - that influence their career development. The external environmental conditions included classical music properties, the effects of regular (as opposed to musically talented) music education, digital music influences, and the musicians' standards of living.

1. Classical music properties (e.g., melody, mode, cord, etc.) had to fit the taste of audiences. As one student recalled, this was not always the case with typical Taiwanese audiences.

Firstly, the audiences do not comprehend the classical music; popular music is easy to understand and sing the songs [as compared to classical music]. Most of the audiences didn't 
know how to read music, so the classical music was too difficult for them. (001, p. 13)

2. Young people are only interested in pop music, resulting in a general decreased understanding of music among the Taiwanese youth.

The way of teaching nonmusically talented students is different.... The regular music education and musically talented music curriculum were completely different and disconnected ... Nobody went to the concerts and appreciated the musician performances. (004, p. 21)

3. Digital music influences music productions; people can stay at home and see the performances.

We had to go to the concert hall and see the musician's performance. Now, we can buy the DVD and see it at any time. Although we need to go on buying the new DVDs, it seems we have lost something. It was difficult to distinguish which one was better. Was it live performances or DVDs? (006, p. 20)

4. The musicians considered whether it would ensure a good standard of living.

I have to work hard in Taiwan in order to support my family. Our salary is as good as the public school teacher's. We didn't have a strict examination system every year so even if you played very well, it was impossible to get a better salary. Nevertheless, we had to work during the weekend and holiday $[s]$.... I practiced violin all my life, and I only earn an average income ... the environment can't support a great musician. (009, p. 13-15)

\section{Individual Factors}

Finally, the researcher found that individual internal and external factors influenced how the participants were received by their audiences. Another phenomenon that affected the musicians' performances was 
the superficial understanding and appreciation of music apparent in the audiences. For instance, at plays and musicals, although the audiences were largely intrigued by the story, costumes, the design of stages, and so forth, they did not care very much for the quality of the musical performance. This in turn led to increased apathy on the part of the musicians.

1. Individual internal factors included perfect performing skills and repertoires.

I think that your repertoire had to fit the taste of audiences; [you could] not just play what music you like.... We used to arrange big pieces ahead of the program, after that we arranged easy and familiar pieces. Finally, we had a choir program, and the audiences could sing with us. (002, pp.19, 24)

How to interpret the music so that it allowed the audience to understand the music or appeal to them? I play music not only because I enjoy it but also because I want to communicate to the audiences. It was very important ... Interpretational ability is a kind of talent, or you could learn it from your teachers; you need to focus your mind to learn it. (003, p. 10)

2. Individual external factors included public relations, dissemination of concerts, musicians' charisma, and appearances.

If you want to hold a concert, you need an agent or public relations company to help you with renting the concert hall, tickets, advertisements, and the press and so on ... A masterpiece was a kind of sell; even the musician's image was a kind of sell too. (002, pp. 17, 19)

\section{Theoretical Considerations and Researcher Reflections}

The role of the parents was very important in that it helped young musically talented students become professional musicians. The parents encouraged them to play the violin; consequently, playing the instrument became an internalized behavior (Feldman, 1991; Kemp, 1996, 1997; Liu, 2001; Sosniak, 1985a, 1985b, 1997; Subotnik \& Jarvin, 2004). However, not all of the parents' involvement was posi- 
tive. Some parents caused these young musicians a great deal of stress and thus restricted some of their creativity. Some of the parents in the United States also were a source of stress to American students studying music and affected their intrinsic motivation and commitment to practice (Subotnik \& Jarvin, 2004).

Most of the music instructors and professors concentrated on training the musically talented students who had highly advanced skills and excelled in music theory. They did not guide the students on how to socialize with their peers. There were differences between Taiwan and the United States during the middle and final stages of developing abilities into scholarly productivity and artistry (Subotnik \& Jarvin, 2004). In other words, learning to socialize with peers was most important for the students in Taiwan because the young classical musicians required a public relations company to help them sell their musical productions.

The musically talented students' challenging career path and the social trends in Taiwan both contribute to decreased appreciation of classical music. Most of the Taiwanese prefer popular music because it is easy to access. There is only one classical music broadcasting station in the northern part of Taiwan and hardly any commercial TV support. Feldman (1991) proposed that a child prodigy's development must mesh with societal trends. Presently, only a few middleand upper class families in Taiwan enjoy classical music.

It was easy to realize that the skills in Taiwan could not catch up with Western countries, making it difficult to cultivate a world-class musician. Feldman (1991, p. 13) argued that the individual's specialized capabilities must fit well with the accumulated knowledge and techniques of a field or domain. The skills of young string players in Taiwan still lag behind those of other young musicians in Western countries, which makes it difficult for them to excel in classical music on a global stage.

There is a hidden value to classical music history influencing cultural development in Taiwan. Although the parents were fixated on their children making adequate sums of money and enjoying good lives in the future, they have the potential to be great musicians and that would be the best result of studying in musically talented classes. They also could become music teachers and still have a good life. According to Feldman's (1991, p. 13) third time frame, historical and 
cultural trends influence both individuals and music fields, which in turn influence each other.

Students are interested in studying many types of music other than classical music. Most people are interested in pop music, jazz, and world music. Classical music was not the only choice, so the classical music learners had to learn other genres of music and create a new life for themselves. Feldman (1991) stated that in the fourth time frame, the evolutionary context, human thought, domains, and culture evolve. In other words, if the four time frames interact and are balanced and coordinated, talented children would appear. The field of classical music is very narrow. If classical music can be expanded to include music from all other cultures' classical music, it would enrich the Taiwanese students, as they only studied about Western classical music. Some young classical musicians' performances crossed over into the popular music field, and the musicians became eminent (e.g., Yo-Yo Ma and Vanessa-Mae). If the Taiwanese musically talented education system does not change the content of the curriculum, it will be difficult to cultivate great musicians.

Finally, although the young generation likes pop music, they sometimes listen to classical music. There were several young talented Asian musicians who won worldwide classical music competitions. The results were an increase in the number of pupils and financial rewards for associated music professors and a good reflection on Taiwan.

\section{Limitations to the Study}

Limitations to the study are based on three factors. First, all of the participants had studied in musically talented classes in Taiwan; the study did not include those who studied abroad during senior high school. Second, all of the participants had studied string instruments, so the results of this study apply to these students and their teachers. Last, the data gathered were dependent on the participants' willingness and the interview guide questions. When participants offered sufficient quantities of information (i.e., all of the categories were saturated), the researcher ceased questioning. 


\section{Conclusion}

This study explored the learning experiences of young string players in the Taiwanese gifted education system. The participants' narrations were coded using the grounded theory approach. The study's results reflect the development of musically talented students' music abilities and temperament. The participants had music-loving and dedicated families who helped them study music at a very young age. They met an important teacher, especially their major instrument teachers, who taught them string playing skills and music interpretations. Finally, the classical music milieu in Taiwan was most important for them becoming a great musician. On the other hand, when parents put a lot of stress on the participants instead of supporting them in their study of music, the participants' passion for and creativity in music was greatly hindered. Furthermore, because of the lack of fertility in the classical music environment in Taiwan, it was arduous to become an accomplished musician.

\section{References}

Bloom, B. S. (1985). Generalizations about talent development. In B. S. Bloom (Ed.), Developing talent in young people (pp. 507-549). New York: Ballantine Books.

Carroll, J. B. (1993). Human cognitive abilities: A survey offactor-analytic studies. New York: Cambridge University Press.

Davidson, L., \& Scripp, L. (1995). Condition of giftedness: Musical development in the preschool and early elementary years. In R. F. Subotnik \& K. D. Arnold (Eds.), Beyond Terman: Contemporary longitudinal studies of talent (pp.155-185). Norwood, NJ: Ablex. (Original work published in 1994)

Feldman, D. H. (1991). Nature's gambit: Child prodigies and the development of human potential. New York: Teachers College Press.

Gardner, H. (1983). Frames of mind: The theory of multiple intelligences. New York: Basic Books.

Glaser, B. C., \& Strauss, A. L. (1967). The discovery of grounded theory. New York: Aldine de Gruyter. 
Gordon, E. E. (1989). Audition, music learning theory, music aptitude, and creativity. In Proceedings of the Suncoast Music Education Forum on Creativity (pp. 75-81). Tampa: University of South Florida. (ERIC Document Reproduction Service No. ED380341)

Ho, Y. C. (2004). The teaching reflection of ground theory's coding: The application of creative and critical interpretation. In Y. H. Ho (Ed.), The new theory of psychology and special education (pp. 327 -357). Taiwan: Psychology Publishing.

Kuo, C. C. (2003). The 30 years follow up study of gifted students: The findings and announcements. Special Education Quarterly, $87,(1-17)$.

Kuo, C. C. (2004). The 30 years of elite education: The findings and announcements of follow up study of gifted students. In Y. H. Ho (Ed.), The new theory of psychology and special education (pp. 279-309). Taiwan: Psychology Publishing.

Kemp, A. E. (1996). The musical temperament: Psychology and personality of musicians. Oxford, UK: Oxford University Press.

Kemp, A. E. (1997). Individual difference in musical behavior. In D. J. Hargreaves \& A. C. North (Eds.), The social psychology of music (pp. 25-45). Oxford, UK: Oxford University Press.

Lebrecht, N. (2001). Who killed classical music? Maestros, managers, and corporate politics. Secaucus, NJ: Birch Lane Press.

Lehmann, A. C., \& Ericsson, K. A. (1998). Historical developments of expert performance: Public performance of music. In A. Steptone (Ed.), Genius and the mind: Studies of creativity and temperament (pp. 67-94). Oxford, UK: Oxford University Press.

Li, C. L. (2001). The exploration of the musically talented classes of Taiwan. Taiwan: The Special Education Center of National Shinchu Teachers College.

Liu, C. H. (2001). Career development of the musically talented: A case study. Journal of Gifted Education. 1(1), 151-171.

Silverman, D. (2000). Doing qualitative research: A practical handbook. Thousand Oaks, CA: Sage.

Sosniak, L. A. (1985a). Learning to be a concert pianist. In B. S. Bloom (Ed.), Developing talent in young people (pp. 19-67). New York: Ballantine Books. 
Sosniak, L. A. (1985b). One concert pianist. In B. S. Bloom (Ed.), Developing talent in young people (pp. 68-89). New York: Ballantine Books.

Sosniak, L. A. (1997). The tortoise, the hare, and the development of talent. In N. Colangelo \& G. A. Davis (Eds.), Handbook of gifted education (2nd ed., pp. 207-217). Needham Heights, MA: Allyn $\&$ Bacon.

Strauss, A., \& Corbin, J. (1998). Basics of qualitative research: Techniques and procedures for developing grounded theory (2nd ed.). Thousand Oaks, CA: Sage.

Subotnik, R. F., \& Jarvin, L. (2004). Beyond expertise: Conception of giftedness as great performance. In R. J. Sternberg \& J. Davidson (Eds.), Conceptions of giftedness (2nd ed.). New York: Cambridge University Press.

Winner, E., \& Martino, G. (2000). Giftedness in non-academic domains: The case of the visual and music. In K. A. Heller, F. J. Mönks, R. J. Sternberg, \& R. F. Subotnik (Eds.), International handbook of giftedness and talent (2nd ed., pp. 95-110). Oxford, UK: Elsevier Science. 


\section{Appendix A}

\section{The Taiwanese Musically Talented Education System}

\begin{tabular}{|c|c|c|c|c|c|c|}
\hline Age & \multicolumn{6}{|c|}{ School and the Fixed Number of Years to Study } \\
\hline 26 & \multirow{4}{*}{\multicolumn{3}{|c|}{ Graduate School in Music }} & 4th year & & \\
\hline 25 & & & & 3 rd year & & \\
\hline 24 & & & & 2nd year & & \\
\hline 23 & & & & 1st year & & \\
\hline 22 & \multirow{5}{*}{$\begin{array}{l}\text { Normal University } \\
\text { Teacher's College } \\
\text { Conservatory }\end{array}$} & 5 th year & & & & \\
\hline 21 & & 4th year & \multirow{4}{*}{$\begin{array}{l}\text { Music } \\
\text { Department } \\
\text { of University }\end{array}$} & 4 th year & & \\
\hline 20 & & 3rd year & & 3rd year & & \\
\hline 19 & & 2nd year & & 2nd year & \multirow{5}{*}{$\begin{array}{l}\text { Music } \\
\text { Department } \\
\text { of Junior } \\
\text { College }\end{array}$} & 5th year \\
\hline 18 & & 1st year & & 1st year & & 4th year \\
\hline 17 & \multirow{3}{*}{$\begin{array}{l}\text { High School } \\
\text { (MTC) }\end{array}$} & 3rd year & \multirow{3}{*}{$\begin{array}{l}\text { Regular } \\
\text { Senior High } \\
\text { School Music }\end{array}$} & 3rd year & & 3rd year \\
\hline 16 & & 2nd year & & 2nd year & & 2nd year \\
\hline 15 & & 1st year & & 1st year & & 1st year \\
\hline 14 & \multirow{3}{*}{$\begin{array}{l}\text { Junior High } \\
\text { School (MTC) }\end{array}$} & 3rd year & \multirow{3}{*}{$\begin{array}{l}\text { Regular } \\
\text { Junior High } \\
\text { School Music } \\
\end{array}$} & 3rd year & & \\
\hline 13 & & 2nd year & & 2nd year & & \\
\hline 12 & & 1st year & & 1st year & & \\
\hline 11 & \multirow{4}{*}{$\begin{array}{l}\text { Elementary School } \\
\text { Musically Talented } \\
\text { Classes (MTC) }\end{array}$} & 6th year & \multirow{6}{*}{$\begin{array}{l}\text { Regular } \\
\text { Elementary } \\
\text { School Music }\end{array}$} & 6th year & & \\
\hline 10 & & 5 th year & & 5 th year & & \\
\hline 9 & & 4th year & & 4th year & & \\
\hline 8 & & 3rd year & & 3rd year & & \\
\hline 7 & \multirow{2}{*}{$\begin{array}{l}\text { Premusically } \\
\text { Talented Classes }\end{array}$} & 2nd year & & 2nd year & & \\
\hline 6 & & 1st year & & 1st year & & \\
\hline 5 & \multirow{2}{*}{\multicolumn{2}{|c|}{$\begin{array}{l}\text { Private music camp (Yamaha } \\
\text { music school) }\end{array}$}} & \multirow[t]{2}{*}{ Preschool } & & & \\
\hline 4 & & & & & & \\
\hline
\end{tabular}

Note. The gray areas highlight the musically talented classes in Taiwan. 


\section{Appendix B}

\section{The Channels of Further Study for Graduated Students of Musically Talented Classes}

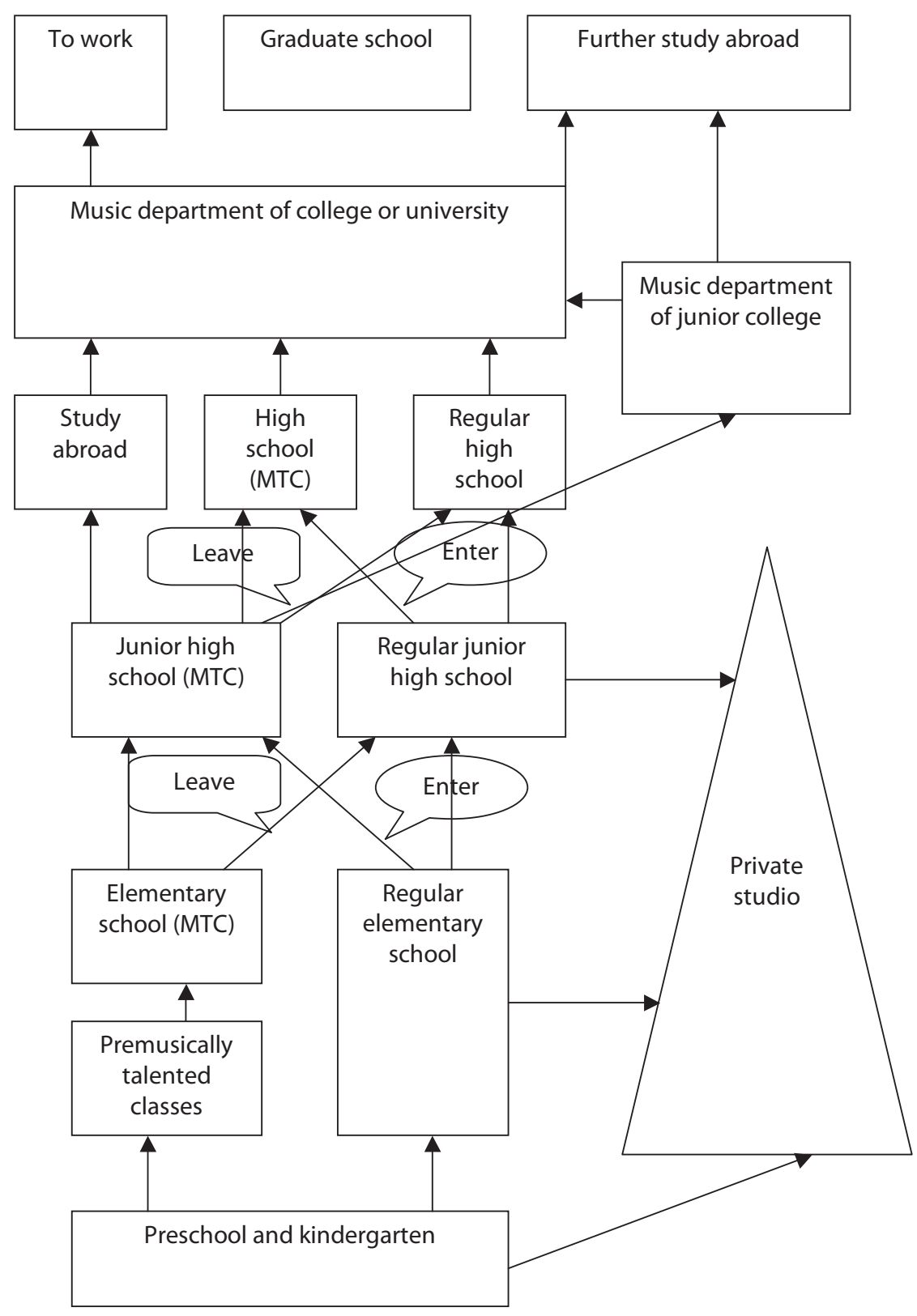

